\title{
The prevalence of oral mucosal lesions in the patients visiting a dental school in Northern India in relation to sex, site and distribution: A retrospective study.
}

\author{
Ramandeep Singh Gambhir ${ }^{1}$, K L Veeresha ${ }^{2}$, Raman Sohi ${ }^{3}$, Heena Kakkar ${ }^{4}$, Amit Aggarwal 5 , Deepak Gup- \\ ta $^{6}$
}

${ }^{1}$ MDS, Senior Lecturer, Department of Preventive and Community Dentistry, Gian Sagar Dental College and Hospital, Banur. ${ }^{2}$ MDS, Prof. \& HOD, Dept. of Preventive and Community Dentistry, M.M. College of Dental Sciences and Research, Mullana, Ambala, Haryana, India.

${ }^{3}$ MDS, Senior Lecturer, Department of Preventive and Community Dentistry, M.M. College of Dental Sciences and Research, Mullana, Ambala, Haryana, India.

${ }^{4}$ BDS, Dental surgeon at Apollo Hospital, Chandigarh.

${ }^{5}$ MDS, Senior Lecturer, Department of Oral Medicine and Radiology, M.M. College of Dental Sciences and Research, Mullana, Ambala, Haryana, India.

${ }^{6}$ BDS, Post Graduate Student, Dept. of Oral Medicine and Radiology, M.M. College of Dental Sciences and Research, Mullana, Ambala, Haryana, India.

Correspondence:

Dept. of oral Medicine and Radiology,

M.M. College of Dental Sciences and Research,

Mullana, Ambala.

E-mail: drdeepak_26@rediffmail.com

Gambhir RS, Veeresha KL, Sohi R, Kakkar H, Aggarwal A, Gupta D. The
prevalence of oral mucosal lesions in the patients visiting a dental school
in Northern India in relation to sex, site and distribution: A retrospective
study. J Clin Exp Dent. 2011;3(1):e10-7.
http://www.medicinaoral.com/odo/volumenes/v3i1/jcedv3ilp10.pdf

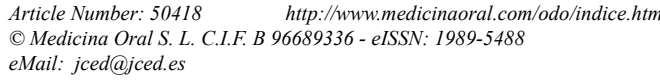

Received: $16 / 10 / 2010$

Accepted: 17/12/2010

\begin{abstract}
Objective: To determine the distribution of oro-mucosal lesions in patients of Maharishi Markendeshwer College of Dental Sciences and Research, (MMCDSR), Mullana. Further to identify sex predilection and different sites which are more susceptible to different oro-mucosal lesions.

Materials and methods: A hospital based retrospective study was carried out from 1st January 2007 till 31st December 2009 at (MMCDSR), Mullana. A total of 451 biopsy reports were studied. Distribution and prevalence of oro-mucosal lesions among the data were analyzed using SPSS software package version 13.

Results: There was no mention of habits in the biopsy reports of $85.4 \%$ (385 patients) of the subjects. Out of the 66 subjects whose habits were mentioned, $71.2 \%$ (47 patients) used to smoke tobacco in one form or the other. $21.2 \%$ (14 patients) used to chew tobacco, $4.5 \%$ (3 patients) of the subjects were in the habit of both smoking and chewing tobacco. More percentage of females $53.1 \%$ were present in the age-group of 11-20 years as compared to males $46.9 \%$ whereas in all other age-groups males were more in number. Regarding the distribution of oral lesions in the oral cavity, buccal mucosa was the common site for the presence of potentially malignant disorders in 16.8 $\%$ of the subjects and it was also the most common site for all the lesions.

Conclusion: Lesion prevalence differed significantly by age, sex, and tobacco use. Individual demographic details such as age, gender, occupation, food habits, other deleterious oral habits, religion and oral hygiene measures should have a provision in biopsy request sheet and should be duly filled which will help in identifying risk-groups. Community programmes should be taken for public health to get them screened for any oral-mucosal lesions by availing pathological lab facilities.
\end{abstract}

Key Words: Oral mucosal lesions, tobacco, community programmes, public health. 


\section{Introduction}

Proper management of a patient with an oral lesion starts with an accurate diagnosis. There are lesions whose diagnosis can be made verifying on data gathered during the history and/or physical examination while there are others which need further confirmation through specialized procedures. Among the various methods available for diagnosing oral lesions, the histopathological examination of a tissue biopsy of the suspicious lesion is regarded as the 'Gold Standard' (1). Retrospective studies to assess the distribution of oro-mucosal lesions are helpful and important in estimating the prevalence of a disease in the population and thus identifying high risk sub-population and help in preventive and curative services.

Different sites in oral cavity show predilection for different types of lesions (1-12). Mucoceles are more commonly seen on lower lip while minor salivary gland tumors are seen most commonly on upper lip. Interaction between genetic and environmental factors in the oral mucosa leads to the formation of a lesion $(1,2)$. These interactions are different in different diseases. Of the variable factors involved in the etiopathogenesis of a lesion, site is an important one (1,2,4-7). Knowledge of site predilection for different diseases will be useful in acknowledging the factors responsible for the same (4-7). A large number of factors may influence the conditions of oral-mucosa and regulate its thresholds against reactions to external irritations and insults. External damage to the tissues may be caused by infections and or other chemical, thermal and mechanical means.

Retrospective studies to assess the distribution of oromucosal lesions are helpful and important in estimating the prevalence of a disease in the population and thus identifying high risk sub-population and help in preventive and curative services.

The present retrospective study was carried out to assess the distribution of oral mucosal lesions among biopsies done in an already existing data of 451 patients who attended as outpatient in the department of Oral Medicine and Radiology at MMCDSR, Mullana during a period of two years (2007-2009) and underwent oral examination and biopsy for their specific oro-mucosal lesions.

\section{Material and Methods}

A hospital based retrospective study was carried out from 1st January 2009 till 31st December 2009 at MMCDSR, Mullana. Only the biopsies performed in dental college were considered. Data regarding biopsy reports was collected on a structured format (Annexure-1). A total of 451 biopsy reports were studied.

Distribution and prevalence of oro-muosal lesions among the data were analyzed using SPSS software package version 13.

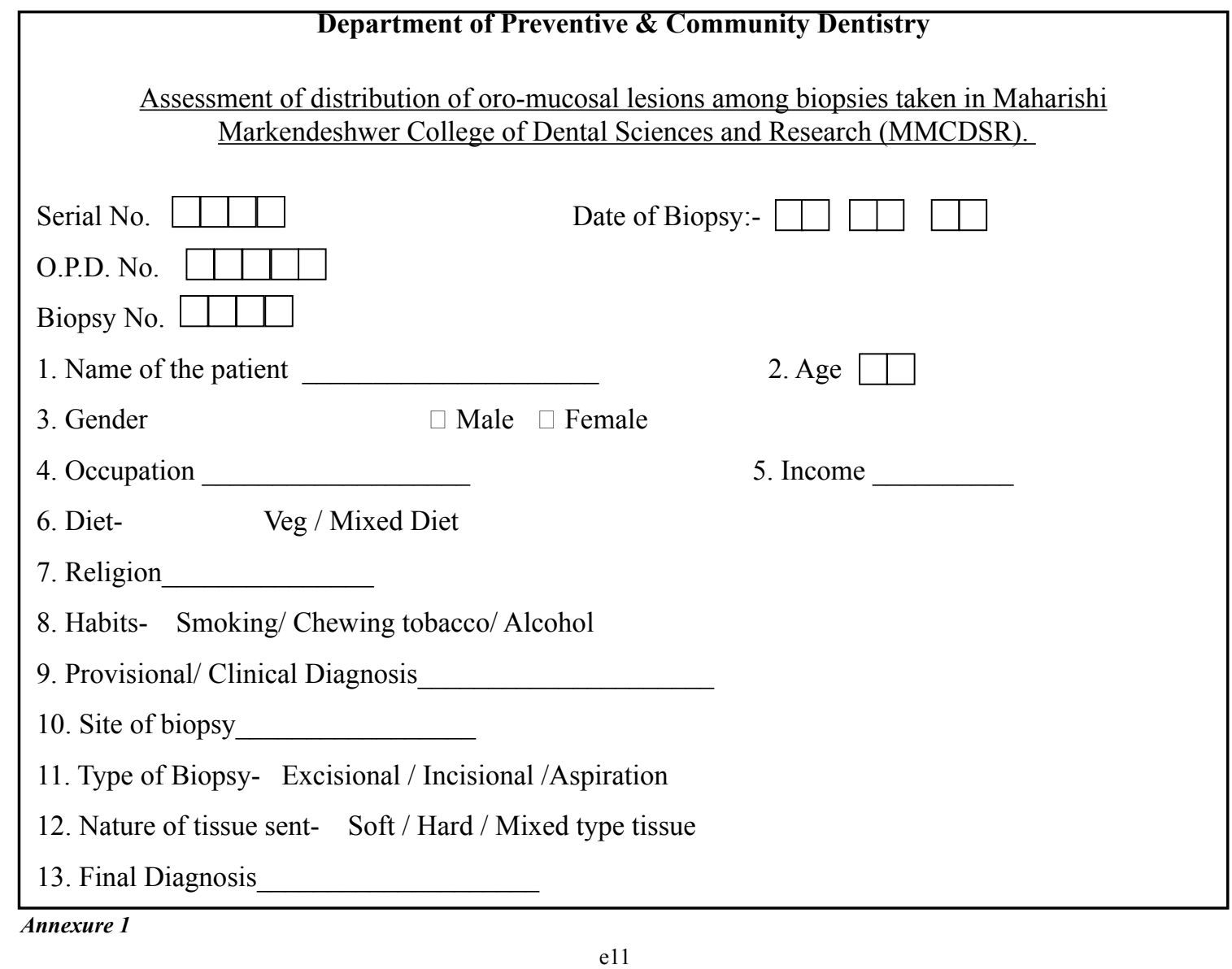




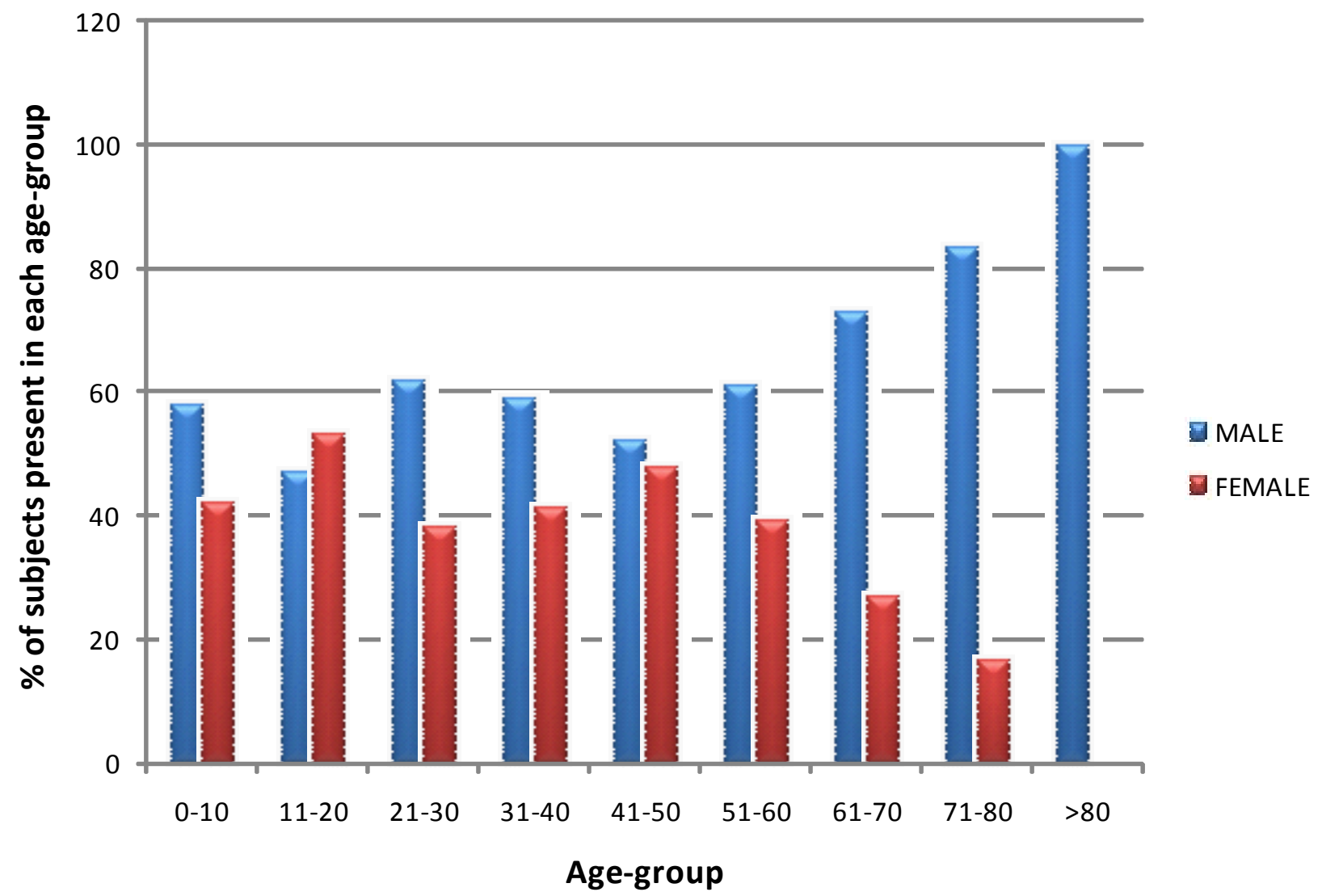

Fig. 1. Percentage distribution of study subjects present in each age-group according to Gender.

\section{Results}

Out of the 451 study subjects, 266 (59\%) were males and $185(41 \%)$ were females.

$4.2 \%$ (19 patients) of the study subjects were in the age group of 0 to 10 years, $14.2 \%$ (64 patients) were in the age group of 11 to 20 years, $18.6 \%$ (84 patients) were in the age group of 21 to 30 years, $21.5 \%$ (97 patients) were in the age group of 31 to 40 years and rest $41.5 \%$ (187 patients) were in the age group of 41 to 80 years.

More percentage of females $(53.1 \%)$ were present in the age-group of 11-20 years as compared to males (46.9\%) whereas in all other age-groups males were more in number (Fig. 1).

Occupation was not mentioned in the biopsy reports of $87.8 \%$ (396 patients) of the subjects. Out of 55 subjects whose occupation was mentioned, $32.7 \%$ (18 patients) were house-wives, $9.0 \%$ (5) of the subjects were shopkeepers, $10.9 \%$ (6) were farmers, $12.7 \%$ (7 patients) were labourers, $20.0 \%$ (11 patients) were students and the remaining were drivers, workers, salesman, teachers and bank-employees.

There was no mention of habits in the biopsy reports of $85.4 \%$ (385 patients) of the subjects. Out of the $66 \mathrm{sub}-$ jects whose habits were mentioned, $71.2 \%$ (47 patients) used to smoke tobacco in one form or the other. $21.2 \%$ (14 patients) used to chew tobacco, 4.5\% (3 patients) of the subjects were in the habit of both smoking and chewing tobacco. Smoking and drug consumption were present in $3.0 \%$ ( 2 patients) of the subjects.

Out of the total of 451 biopsies, 30.6\% (138) were taken from buccal mucosa, $15.5 \%$ (70) were taken from the alveolar region, $9.8 \%$ (44) were taken from the gingiva, $2.2 \%$ (10) were taken from extraoral region, 9.8\% (44) were taken from the vestibular region and the remaining were taken from other sites of the oral cavity like tongue, palatal region, submandibular region etc.

Out of 451 biopsies that were taken, 61.9\% (279) were taken as incisional biopsies, 33\% (149) were taken as excisional biopsies, $0.2 \%$ were taken as aspirational and $0.7 \%$ of the subjects underwent marsupialization.

$86.7 \%$ (391) were soft tissues that were sent for biopsies, $3.3 \%$ (15) were hard tissues and rest was mixed tissues. Out of a total of 451 study subjects, $22.2 \%$ (101) of the subjects were provisionally diagnosed of having potentially malignant disorders like leukoplakia, lichen planus, oral submucous disorders etc. $19.5 \%$ (88) of the subjects were provisionally diagnosed to be suffering from soft tissue tumours like irritational fibroma, pyogenic grauloma, lipoma etc. Developmental disturbances of oral and paraoral structures were initially diagnosed to be present in $2.7 \%$ (12) of the study specimens. Carcinomas, both of specific and non-specific type were initially thought to be present in $7.5 \%$ (34) of the study specimens. The remaining $48 \%$ of the subjects were initially diagnosed 


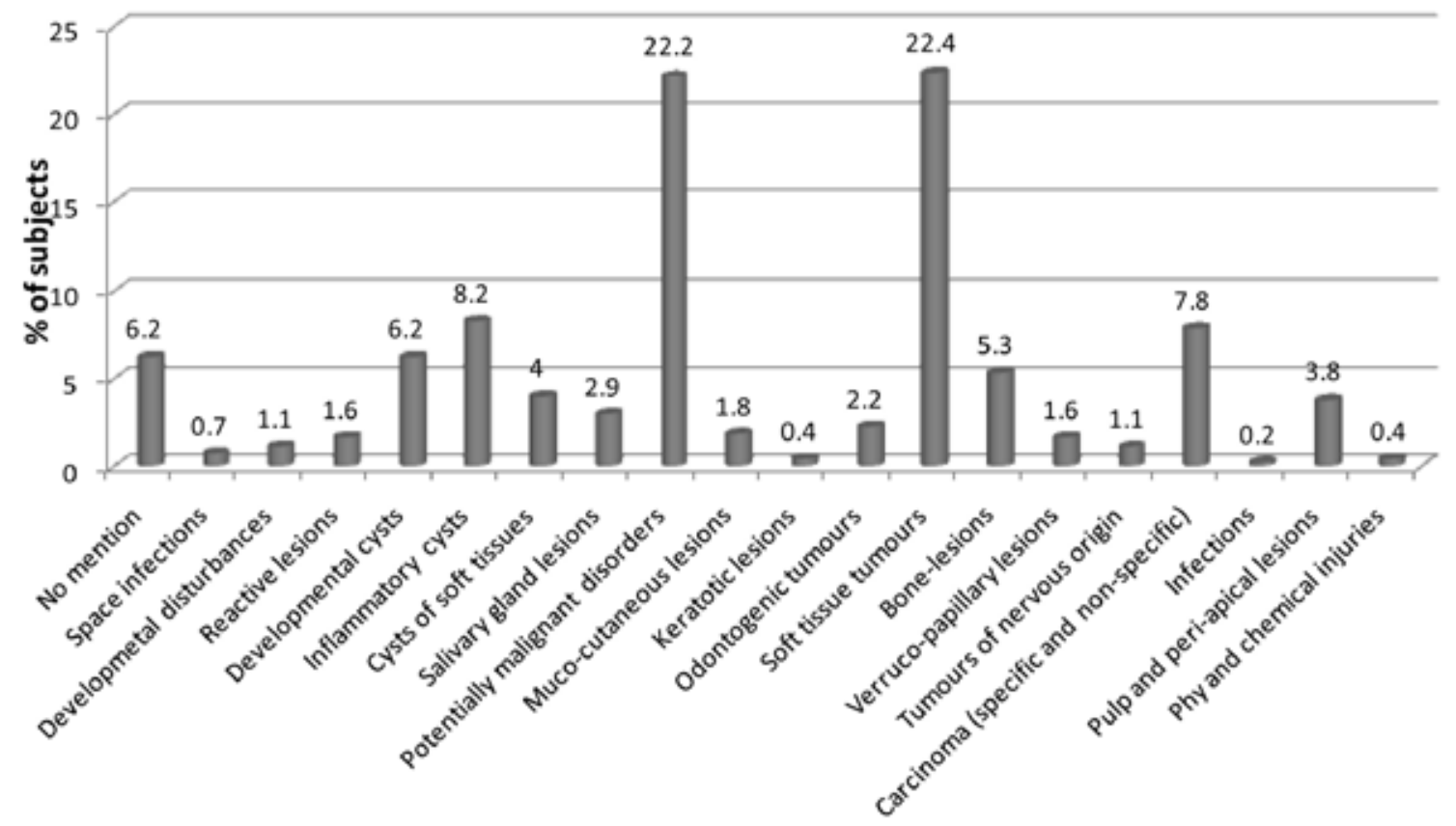

Final Diagnosis

Fig. 2. Distribution of study specimens according to the Final Diagnosis of the oral lesion.

of having reactive lesions, keratotic lesions, pulp and periapical lesions, developmental cysts etc.

Out of the total number of 451 study subjects (Table 2). $22.4 \%$ (101 patients) were ultimately diagnosed to be suffering from soft tissue tumours like irritational fibroma, pyogenic granuloma and was also found to be the most common oro-mucosal lesion. $22.2 \%$ (100 patients) were finally diagnosed to be suffering from potentially malignant disorders like lichen planus, leukoplakia etc. with severity ranging from mild to severe epithelial dys- plasia and was found to be the second most common oro-mucosal lesion. Carcimomas (specific and non-specific) were found to be present in $7.8 \%$ (35 patients) of the study specimens ranging from squamous cell carcinomas, verrucous carcinomas to ulcer (Fig. 2).

Among men, potentially malignant disorders and carcinomas were more prevalent compared to other soft tissue lesions, whereas among women soft tissue tumours and infections were more prevalent (Fig. 3).

Regarding the distribution of oral lesions in the oral ca-

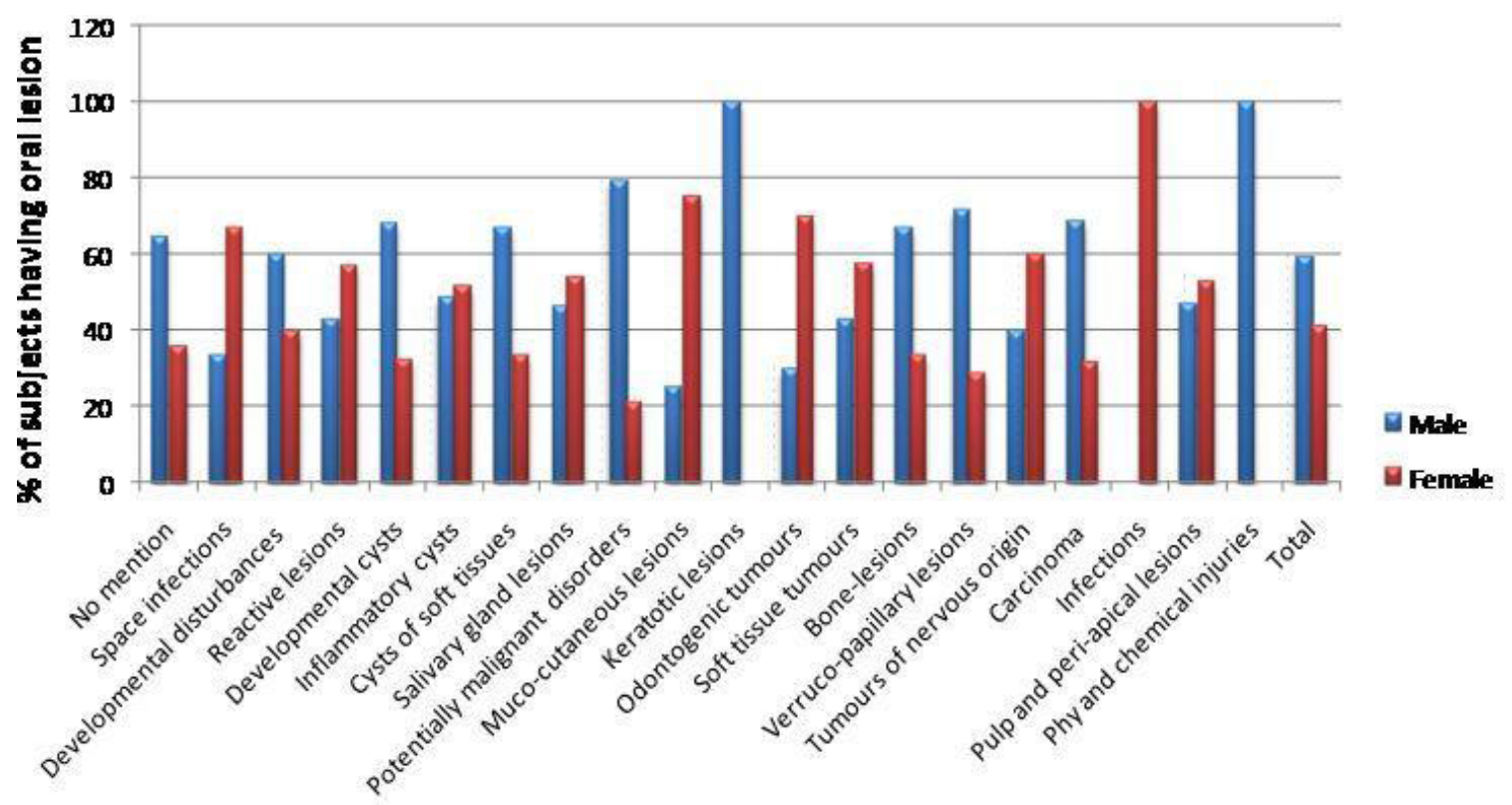

Final Diafnosis

Fig. 3. Percentage Distribution of Final Diagnosis of oral lesion with Gender 
vity, buccal mucosa was the common site for the presence of potentially malignant disorders in $16.8 \%$ of the subjects and it was also the most common site for all the lesions whereas alveolar region was the most common site involved in inflammatory cysts in $6.4 \%$ of the study specimens [Table 1(a)]. 3.7\% of the subjects had carcinomas confined to buccal mucosa. The main site for soft tissue tumours was also buccal mucosa in $4.2 \%$ of the subjects with less involvement of palate and vestibular region [Table $1(\mathrm{~b})]$.

Potentially malignant disorders were most common in the age-group of 31-40 years whereas developmental disturbance and mucocutaneous lesions were more prevalent in the age-group of 11-20 and 41-50 years respectively [Table 2(a)]. Soft tissue tumours were most common in the age-group of 31-40 years. The development of oro-mucosal lesions was significantly related with age [Table $2(\mathrm{~b})]$.

\begin{tabular}{|c|c|c|c|c|c|c|c|c|c|c|c|}
\hline \multirow{2}{*}{$\begin{array}{c}\text { Final } \\
\text { diagnosis }\end{array}$} & \multicolumn{11}{|c|}{ Main sites of oral lesions } \\
\hline & $\begin{array}{c}\text { Vestibular } \\
\text { region }\end{array}$ & $\begin{array}{l}\text { Buccal } \\
\text { mucosa }\end{array}$ & $\begin{array}{c}\text { Labial } \\
\text { mucosa }\end{array}$ & Tongue & $\begin{array}{c}\text { Alveolar } \\
\text { region }\end{array}$ & Tooth & $\begin{array}{c}\text { Extra- } \\
\text { oral }\end{array}$ & Palate & $\begin{array}{l}\text { Lingual } \\
\text { mucosa }\end{array}$ & Jaw & Gingiva \\
\hline $\begin{array}{c}\text { Space } \\
\text { infections }\end{array}$ & $0(0)$ & $0(0)$ & $0(0)$ & $0(0)$ & $3(0.6)$ & $0(0)$ & $0(0)$ & $0(0)$ & $0(0)$ & $0(0)$ & $0(0)$ \\
\hline $\begin{array}{l}\text { Developmental } \\
\text { disturbances }\end{array}$ & $0(0)$ & $1(0.2)$ & 0 & 0 & 0 & $1(0.2)$ & 0 & 0 & 0 & 0 & $3(0.6)$ \\
\hline $\begin{array}{c}\text { Reactive } \\
\text { lesions }\end{array}$ & $2(0.4)$ & $0(0)$ & $1(0.2)$ & $0(0)$ & $2(0.4)$ & $2(0.4)$ & $0(0)$ & $0(0)$ & $0(0)$ & $0(0)$ & $0(0)$ \\
\hline $\begin{array}{l}\text { Developmental } \\
\text { cysts }\end{array}$ & $9(1.9)$ & $2(0.4)$ & $0(0)$ & $0(0)$ & $3(0.6)$ & $10(2.2)$ & $0(0)$ & $0(0)$ & $0(0)$ & $2(0.4)$ & $2(0.4)$ \\
\hline $\begin{array}{l}\text { Inflammatory } \\
\text { cysts }\end{array}$ & $4(0.8)$ & $1(0.2)$ & $0(0)$ & $0(0)$ & $29(6.4)$ & $1(0.2)$ & $0(0)$ & $1(0.2)$ & $0(0)$ & $0(0)$ & $1(0.2)$ \\
\hline $\begin{array}{l}\text { Cysts of soft } \\
\text { tissues }\end{array}$ & $0(0)$ & $2(0.4)$ & $12(2.6)$ & $1(0.2)$ & $0(0)$ & $0(0)$ & $1(0.2)$ & $0(0)$ & $1(0.2)$ & $0(0)$ & $0(0)$ \\
\hline $\begin{array}{l}\text { Salivary gland } \\
\text { lesions }\end{array}$ & $1(0.2)$ & $1(0.2)$ & $1(0.2)$ & $1(7.7)$ & $1(0.2)$ & $0(0)$ & $2(0.4)$ & $3(0.6)$ & $0(0)$ & $1(0.2)$ & $1(0.2)$ \\
\hline $\begin{array}{c}\text { Potentially } \\
\text { malignant } \\
\text { disorders }\end{array}$ & $5(1.1)$ & $\begin{array}{c}76 \\
(16.8)\end{array}$ & $11(2.4)$ & $1(0.2)$ & $1(0.2)$ & $0(0)$ & $0(0)$ & $3(0.6)$ & $2(0.4)$ & $0(0)$ & $0(0)$ \\
\hline $\begin{array}{l}\text { Muco- } \\
\text { cutaneous } \\
\text { lesions }\end{array}$ & $0(0)$ & $5(1.1)$ & $0(0)$ & $0(0)$ & $0(0)$ & $0(0)$ & $2(0.4)$ & $0(0)$ & $0(0)$ & $0(0)$ & $1(0.2)$ \\
\hline
\end{tabular}

\begin{tabular}{|c|c|c|c|c|c|c|c|c|c|c|c|}
\hline \multirow{2}{*}{$\begin{array}{c}\text { Final } \\
\text { diagnosis }\end{array}$} & \multicolumn{11}{|c|}{ Main sites of oral lesions } \\
\hline & $\begin{array}{c}\text { Vestibule } \\
\text { region }\end{array}$ & $\begin{array}{l}\text { Buccal } \\
\text { mucosa }\end{array}$ & $\begin{array}{l}\text { Labial } \\
\text { mucosa }\end{array}$ & $\begin{array}{l}\text { Ton- } \\
\text { gue }\end{array}$ & $\begin{array}{l}\text { Alveolar } \\
\text { region }\end{array}$ & Tooth & $\begin{array}{c}\text { Extra- } \\
\text { oral }\end{array}$ & Palate & $\begin{array}{l}\text { Lingual } \\
\text { mucosa }\end{array}$ & Jaw & Gingiva \\
\hline $\begin{array}{l}\text { Keratotic } \\
\text { lesions }\end{array}$ & $0(0)$ & $0(0)$ & $1(0.2)$ & $0(0)$ & $0(0)$ & $0(0)$ & $0(0)$ & $1(0.2)$ & $0(0)$ & $0(0)$ & $0(0)$ \\
\hline $\begin{array}{l}\text { Odontogenic } \\
\text { tumours }\end{array}$ & $3(0.6)$ & $0(0)$ & $0(0)$ & $0(0)$ & $3(0.6)$ & $1(0.2)$ & $0(0)$ & $0(0)$ & $0(0)$ & $1(0.2)$ & $0(0)$ \\
\hline $\begin{array}{c}\text { Soft tissue } \\
\text { tumours }\end{array}$ & $7(1.5)$ & $19(4.2)$ & $5(1.1)$ & $4(0.8)$ & $9(1.9)$ & $1(0.2)$ & $2(0.4)$ & $13(2.8)$ & $1(0.2)$ & $6(1.3)$ & $28(6.2)$ \\
\hline Bone-lesions & $4(0.8)$ & $1(0.2)$ & $0(0)$ & $0(0)$ & $0(0)$ & $2(0.4)$ & $0(0)$ & $1(0.2)$ & $0(0)$ & $10(2.2)$ & $4(0.8)$ \\
\hline $\begin{array}{c}\text { Verruco- } \\
\text { papillary } \\
\text { lesions }\end{array}$ & $0(0)$ & $2(0.4)$ & $0(0)$ & $2(0.4)$ & $0(0)$ & $0(0)$ & $1(0.2)$ & $2(0.4)$ & $0(0)$ & $0(0)$ & $0(0)$ \\
\hline $\begin{array}{c}\text { Tumours of } \\
\text { nervous origin }\end{array}$ & $1(0.2)$ & $0(0)$ & $0(0)$ & $1(0.2)$ & $0(0)$ & $0(0)$ & $2(0.4)$ & $1(0.4)$ & $0(0)$ & $0(0)$ & $0(0)$ \\
\hline Carcinoma & $6(1.3)$ & $17(3.7)$ & $2(0.4)$ & $2(0.4)$ & $4(0.8)$ & $0(0)$ & $0(0)$ & $0(0)$ & $1(0.2)$ & $0(0)$ & $1(0.2)$ \\
\hline Infections & $0(0)$ & $1(0.2)$ & $0(0)$ & $0(0)$ & $0(0)$ & $0(0)$ & $0(0)$ & $0(0)$ & $0(0)$ & $0(0)$ & $0(0)$ \\
\hline $\begin{array}{l}\text { Pulp and peri- } \\
\text { apical lesions }\end{array}$ & $0(0)$ & $0(0)$ & $0(0)$ & $0(0)$ & $12(2.6)$ & $4(0.8)$ & $0(0)$ & $0(0)$ & $0(0)$ & $0(0)$ & $1(0.2)$ \\
\hline
\end{tabular}

Values in parenthesis ( ) denote percentage

Table 1. Percentage distribution of study specimens according to the final diagnosis and site of the lesion

\section{Table 1a.}




\begin{tabular}{|c|c|c|c|c|c|c|c|c|c|c|}
\hline Final & \multicolumn{7}{|c|}{ Age Group of the study specimens } \\
\cline { 2 - 6 } & $\mathbf{0 - 1 0}$ & $\mathbf{1 1 - 2 0}$ & $\mathbf{2 1 - 3 0}$ & $\mathbf{3 1 - 4 0}$ & $\mathbf{4 1 - 5 0}$ & $\mathbf{5 1 - 6 0}$ & $\mathbf{6 1 - 7 0}$ & $\mathbf{7 1 - 8 0}$ & $>\mathbf{8 0}$ & Total \\
\hline $\begin{array}{c}\text { Space } \\
\text { infections }\end{array}$ & $0(0)$ & $0(0)$ & $1(33.3)$ & $1(33.3)$ & $0(0)$ & $1(33.3)$ & $0(0)$ & $0(0)$ & $0(0)$ & $3(0.7)$ \\
\hline $\begin{array}{c}\text { Developmental } \\
\text { disturbances }\end{array}$ & $1(20)$ & $3(60)$ & $1(20)$ & $0(0)$ & $0(0)$ & $0(0)$ & $0(0)$ & $0(0)$ & $0(0)$ & $5(1.1)$ \\
\hline $\begin{array}{c}\text { Reactive } \\
\text { lesions }\end{array}$ & $0(0)$ & $0(0)$ & $2(28.6)$ & $2(28.6)$ & $0(0)$ & $3(42.9)$ & $0(0)$ & $0(0)$ & $0(0)$ & $7(1.5)$ \\
\hline $\begin{array}{c}\text { Developmental } \\
\text { cysts }\end{array}$ & $3(10.7)$ & $6(21.4)$ & $8(28.6)$ & $4(14.3)$ & $4(14.3)$ & $3(10.7)$ & $0(0)$ & $0(0)$ & $0(0)$ & $28(6.2))$ \\
\hline $\begin{array}{c}\text { Inflammatory } \\
\text { cysts }\end{array}$ & $1(2.7)$ & $8(21.6)$ & $13(35.1)$ & $8(21.6)$ & $2(5.4)$ & $3(8.1)$ & $2(5.4)$ & $0(0)$ & $0(0)$ & $37(8.2)$ \\
\hline $\begin{array}{c}\text { Cysts of soft } \\
\text { tissues }\end{array}$ & $0(0)$ & $6(33.3)$ & $4(22.2)$ & $4(22.2)$ & $3(16.7)$ & $0(0)$ & $0(0)$ & $1(5.6)$ & $0(0)$ & $18(4.0)$ \\
\hline $\begin{array}{c}\text { Salivary gland } \\
\text { lesions }\end{array}$ & $0(0)$ & $1(7.7)$ & $3(23.1)$ & $1(7.7)$ & $4(30.8)$ & $1(7.7)$ & $3(23.1)$ & $0(0)$ & $0(0)$ & $13(2.9)$ \\
\hline $\begin{array}{c}\text { Potentially } \\
\text { malignant } \\
\text { disorders }\end{array}$ & $0(0)$ & $2(2)$ & $17(17)$ & $27(27)$ & $21(21)$ & $24(24)$ & $7(7)$ & $2(0)$ & $0(0)$ & $100(22.2)$ \\
\hline $\begin{array}{c}\text { Muco- } \\
\text { cutaneous } \\
\text { lesions }\end{array}$ & $0(0)$ & $0(0)$ & $1(12.5)$ & $2(25)$ & $3(37.5)$ & $2(25)$ & $0(0)$ & $0(0)$ & $0(0)$ & $8(1.8)$ \\
\hline
\end{tabular}

Values in parenthesis () denote percentage

\begin{tabular}{|c|c|c|c|c|c|c|c|c|c|c|}
\hline Final \\
diagnosis & $\mathbf{0 - 1 0}$ & $\mathbf{1 1 - 2 0}$ & $\mathbf{2 1 - 3 0}$ & $\mathbf{3 1 - 4 0}$ & $\mathbf{4 1 - 5 0}$ & $\mathbf{5 1 - 6 0}$ & $\mathbf{6 1 - 7 0}$ & $\mathbf{7 1 - 8 0}$ & $>\mathbf{8 0}$ & Total \\
\hline $\begin{array}{c}\text { Keratotic } \\
\text { lesions }\end{array}$ & $0(0)$ & $1(50)$ & $0(0)$ & $1(50)$ & $0(0)$ & $0(0)$ & $0(0)$ & $0(0)$ & $0(0)$ & $2(0.4)$ \\
\hline $\begin{array}{c}\text { Odontogenic } \\
\text { tumours }\end{array}$ & $0(0)$ & $4(40)$ & $3(30)$ & $2(20)$ & $1(10)$ & $0(0)$ & $0(0)$ & $0(0)$ & $0(0)$ & $10(2.2)$ \\
\hline $\begin{array}{c}\text { Soft tissue } \\
\text { tumours }\end{array}$ & $4(4)$ & $19(18.8)$ & $13(12.9)$ & $22(21.8)$ & $14(13.9)$ & $13(12.9)$ & $11(10.9)$ & $5(5)$ & $0(0)$ & $101(22.4)$ \\
\hline Bone-lesions & $0(0)$ & $5(20.8)$ & $7(29.2)$ & $2(8.3)$ & $4(16.7)$ & $2(8.3)$ & $2(8.3)$ & $2(8.3)$ & $0(0)$ & $24(5.3)$ \\
\hline $\begin{array}{c}\text { Verruco- } \\
\text { papillary } \\
\text { lesions }\end{array}$ & $0(0)$ & $1(14.3)$ & $2(28.6)$ & $0(0)$ & $2(28.6)$ & $2(28.6)$ & $0(0)$ & $0(0)$ & $0(0)$ & $7(1.6)$ \\
\hline $\begin{array}{c}\text { Tumours of } \\
\text { nervous origin }\end{array}$ & $0(0)$ & $1(20)$ & $0(0)$ & $2(40)$ & $1(20)$ & $1(20)$ & $0(0)$ & $0(0)$ & $0(0)$ & $5(1.1)$ \\
\hline Carcinoma & $0(0)$ & $1(2.9)$ & $2(5.7)$ & $8(22.9)$ & $6(17.1)$ & $6(17.1)$ & $10(28.6)$ & $1(2.9)$ & $1(2.9)$ & $35(7.8)$ \\
\hline $\begin{array}{c}\text { Pulp and peri- } \\
\text { apical lesions }\end{array}$ & $4(23.5)$ & $3(17.6)$ & $5(23.5)$ & $4(29.4)$ & $1(5.9)$ & $0(0)$ & $0(0)$ & $0(0)$ & $0(0)$ & $17(3.8)$ \\
\hline Total & $19(4.2)$ & $64(14.2)$ & $84(18.6)$ & $97(21.5)$ & $67(14.9)$ & $69(15.3)$ & $37(8.2)$ & $12(2.7)$ & $2(0.4)$ & $451(100)$ \\
\hline
\end{tabular}

Values in parenthesis () denote percentage

Table 2. Number distribution of study subjects having the oral lesion according to the age-group

Table $2 a$.

Table $2 b$.

\section{Discussion}

Prevalence studies in dentistry are mostly based on either the examination of total population samples or dental out patients. For the first time, a record study for assessment and distribution of oro-mucosal lesions among biopsies in MMCDSR was done. The importance was given for the specimens rather than the individual as the study was done on the outpatients in the dental college and that too among those who were suspected of the lesion and needed pathological diagnosis.

It has been found that more biopsies were taken in males than females. In the present study, more number of male subjects were suffering from oro-mucosal lesions as compared to females which was different than that 
reported by Mikkonen et al. (2). It could be due to the more prevalence of deleterious oral habits among males than females. The prevalence of white lesions like leukoplakia in females in this study was same as that reported by Osterberg et al. (3) whereas in case of men there was higher prevalence.

Regarding the types of oral lesions biopsied, more number of lesions were reported in the study as compared to the study done by Vasconceles et al. (4). The most frequent oral lesion in the study was soft tissue tumors which is different to that reported by Vasconceles et al. (4).

Regarding the site for the development of oro-mucosal lesions, the main site reported in this study was buccal mucosa which was similar as that reported by GarcíaPola et al. (5) and Mathew et al. (6). This indicates more prevalence of habits like pan-chewing, khaini etc. The main site for the development of leukoplakia in the study was also buccal mucosa which was different than that reported by Ikeda et al. (9). The presence of tongue lesions in this study was very less than that reported by Darwazeh et al. (13). The most common site of carcinoma is also buccal mucosa reported in this study whereas in the study by Mirbod (7) it is the posterior ventrolateral border of the tongue. Prevalence of oral lesions like lichen planus and leukoplakia in the study was same as that reported by Axell et al. (8). Same percentage of subjects had cysts of soft tissues like mucocele in the study and that reported by Axell et al. (8) but more as compared to the study done by Mathew et al. (6).

It is surprising to note that $12 \%$ of the biopsies taken were below the age of 10 years. This could be due to congenital and developmental abnormalities suspected to be confirmed as due to more number of consensual marriages in Haryana.

The age related prevalence of oro-mucosal lesions in the present study was different than that reported by Mikkonen et al. (2) There was also marked age-related increase in oral cancer in the study which was same as that reported by Malaovalla (1). The prevalence of fungal infections like candida was less in the study than that reported by Vallejo (5) and Aguirre et al. (10).

It has been found that oro-mucosal lesions had high prevalence in the age-group of 31-40 years. This could be attributed to their long-standing oral habits. Maximum number of provisional diagnosis made clinically $(95 \%)$ was confirmed pathologically in this study.

Soft tissue tumours and potentially malignant disorders were the most common finding in the study subjects which correlated with other studies. Carcinomas were most common in males than females which correlated with other studies. The prevalence of oral cancer in this study was less than that reported by Malaovalla (1). There was also marked age-related increase in oral cancer in the study which was same as that reported by Malaova- lla (1).

The prevalence of fungal infections like candida was less in the study than that reported by Aguirre et al. (10).

Certain lesions like developmental disturbances of oral and paraoral structures, developmental cysts and inflammatory, tumours of nervous origin, physical and chemical injuries were only present in this study and had very less prevalence or no reporting in other studies.

The most common finding in this study was soft tissue tumours (22.4\%) presenting as fibroma, pyogenic grauloma etc. Potentially malignant disorders like leukoplakia, lichen planus were the second most common findings in the study (22.2\%). Among men, potentially malignant disorders and carcinomas were more prevalent as compared to other soft tissue lesions, whereas among women soft tissue tumors and infections were more prevalent.

Majority of the subjects were in the age-group of 3140 years $(21.5 \%)$. Age was significantly related with the development of oro-mucosal lesions.

Occupation was not mentioned in large majority of the biopsy reports. Among the mentioned ones, house-wives were more in number. Majority of the subjects (10.4\%) used to smoke tobacco in one form or the other. Majority of the biopsies (30.6\%) were taken from the buccal mucosa and less from the alveolar region, gingiva and other regions of the oral cavity. Further most of the biopsies $(61.9 \%)$, were taken as incisional biopsies for diagnosis of oral lesions.

We stress that individual demographic details such as age, gender, occupation, food habits, other deleterious oral habits, religion and oral hygiene measures should have a provision in biopsy request sheet and should be duly filled which will help in identifying risk-groups. Further, community programmes should be taken to educate the population to get them screened for any oral-mucosal lesions by availing pathological laboratory facilities.

\section{References}

1. Malaovalla AM, Silverman S, Mani NJ, Bilimoria KF, Smith LW. Oral cancer in 57,518 industrial workers of Gujarat, India: a prevalence and follow-up study. Cancer. 1976;37:1882-6.

2. Mikkonen M, Nyyssönen V, Paunio I, Rajala M. Prevalence of oral mucosal lesions associated with wearing removable dentures in Finnish adults. Community Dent Oral Epidemiol. 1984;12:191-4.

3. Osterberg T, Ohman A, Heyden G, Svanborg A. The condition of oral mucosa at age 70: a population study. Gerodontology. 1985;4:71-5.

4. Vasconcelos BC, Novaes M, Sandrini FA, Maranhão Filho AW, Coimbra LS. Prevalence of oral mucosa lesions in diabetic patients: a preliminary study. Braz J Otorhinolaryngol. 2008;74:423-8.

5. García-Pola Vallejo MJ, Martínez Díaz-Canel AI, García Martín JM, González García M. Risk factors for oral soft tissue lesions in an adult Spanish population. Community Dent Oral Epidemiol. 2002;30:277-85.

6. Mathew AL, Pai KM, Sholapurkar AA, Vengal M. The prevalence of oral mucosal lesions in patients visiting a dental school in Southern India. Indian J Dent Res. 2008;19:99-103. 
7. Mirbod SM, Ahing SI. Tobacco-associated lesions of the oral cavity: Part II. Malignant lesions. J Can Dent Assoc. 2000; 66: 30811.

8. Axéll T, Zain RB, Siwamogstham P, Tantiniran D, Thampipit J. Prevalence of oral soft tissue lesions in out-patients at two Malaysian and Thai dental schools. Community Dent Oral Epidemiol. 1990;18:95-9.

9. Ikeda N, Ishii T, Iida S, Kawai T. Epidemiological study of oral leukoplakia based on mass screening for oral mucosal diseases in a selected Japanese population. Community Dent Oral Epidemiol. 1991;19:160-3.

10. Aguirre JM, Verdugo F, Zamacona JM, Quindos G, Ponton J. Cytological changes in oral mucosa in denture stomatitis. Gerdontology. 1996;13:63-7.

11. Reichart PA, Schmidtberg W, Scheifele C. Betel chewer's mucosa in elderly Cambodian women. J Oral Pathol Med. 1996;25:36770.

12. Rooban T, Rao A, Joshua E, Ranganathan K. The prevalence of oral mucosal lesions in alcohol misusers in Cheenai, south India. Indian J Dent Res. 2009;20:41-6.

13. Darwazeh AMG, Pillai K. Prevalence of tongue lesions in 1013 Jordanian dental outpatients. Community Dent Oral Epidemiol. $1993 ; 21: 323-24$. 